National Park, he took a keen interest in the FPS's work in international wildlife conservation. He had planned to make a special visit to London in March for the dinner to mark Lord Willingdon's retirement as President, and it was with great sadness that we learned of his death the previous month.

\title{
Britain and the Trade Convention
}

\section{Solicitor General at Annual General Meeting}

Mr Peter Archer QC, MP, the Solicitor General, was the speaker at the FPS Annual General Meeting on July 2nd, presided over by our President. After being welcomed by Lord Zuckerman, Mr Archer, who is a member of FPS, gave us a forthright talk about conservation legislation. He pointed out that the day before the meeting, July 1st, had been a milestone for wildlife conservation with the coming into force of the International Convention on Trade in Endangered Species, twelve nations having ratified the Convention. Unfortunately, Britain was not one of them. He agreed that the UK was in a position to ratify, since UK legislation complied with the Convention, deriving from an Act passed in 1939 under war-time conditions, which 'works in a rusty, creaky sort of way'; but not all our dependent territories, whom we had promised to include in our ratification (and they could not be added later if we ratified without them) were prepared to accept this Act as a basis for their own legislation. New legislation is planned, but not yet drafted, and it was largely the bottleneck in the parliamentary draftsmen's office that is now blocking progress. There was a great shortage of skilled draftsmen.

Another delaying factor was the Government's belief that the Convention would be much more effectively worked if our trading partners, i.e. the other eight EEC member nations, ratified at the same time, and so far none had done so. 'The object of the Convention', said Mr Archer, 'is not to get a signature on a piece of paper, but to get effective control over the trade in endangered species. But we do intend, as soon as possible, to have a new Act which is tailor-made for the purpose'.

\section{Elections}

Lord Zuckerman spoke of the deaths of three Vice-Presidents of the Society during the year, all of whom had given long and much valued services: Syed W. Ameer Ali CIE ICS (retd.); Professor J.G. Baer, and Sir Julian Huxley FRS. One new Vice-President was elected, Lt Col C.L. Boyle OBE, former Hon. Secretary of the Society.

Three members of Council retired and were warmly thanked for their services: J.C. Cadbury, Dr Malcolm J. Coe and Ian S. MacPhail. Mr MacPhail's appointment as Public Relations Officer was confirmed. Five names put forward to fill the vacancies on Council were confirmed: G.T. Corley Smith CMG, Dr Keith Eltringham, Stuart Johnstone, the Hon. Ivor Montagu and Dr John Owen.

Sir Peter Scott, our Chairman proposed a vote of thanks to the Zoological Society of London for much help and kindness throughout the year and especially for the provision of office accommodation and services.

Council's proposal, put forward by the Hon. Treasurer, that the subscription should be raised from $£ 3$ to $£ 5$ was approved. (See page 224.) 
A wine and cheese supper was served after the meeting and members were then able to walk in the Zoo gardens, by special invitation of the Zoological Society, on what proved to be a beautiful summer evening.

\section{Whales and Whaling: a Dance of Death}

\section{Richard Fitter}

The whaling industry and its raw material, the whale stocks of the world, continue their grim Totentanz towards their mutual extinction. The most significant event of the 27th meeting of the International Whaling Commission in London in June, and one of the least publicised, was the Soviet announcement that next season they would have only two instead of three Antarctic expeditions. And, in fulfilment of the classic Parkinsonian theory, the IWC is about to get itself a full-time secretary and new offices in Cambridge just as the industry which provides its raison d'etre has reached the brink of the precipice of its final decline. For the most significant event of all was one which was ignored at the meeting: the current experiments by Norway, West Germany, and other nations into the harvesting of krill. Since harvesting the top of the food chain is always the most uneconomic method of using natural resources, it may well be that in human terms it is more economic for men rather than whales to feed on krill. But there can be no doubt that a thoroughgoing effort to harvest krill would mean the virtual end of the whaling industry, by depriving the great baleen whales of their food. But this prospect did not seem sufficiently real to the IWC mandarins to warrant their discussing it-again a classic reaction to imminent extinction.

The main actual achievement of the 27th meeting was the classification of whale stocks into three categories: Protection Stocks, on which there would be a total moratorium; Sustained Management Stocks, where a strict control of commercial whaling would be exercised; and Initial Management Stocks, where the stock is above the maximum sustainable yield and commercial whaling would be allowed subject to controls to avoid overexploitation (such as has just undoubtedly occurred with the newly exploited minke whale in the Antarctic). The list of devastated whale stocks that have had to be placed in categories one and two, and which are a measure of the crushing failures of the IWC in the past, is shamefully long. If one is prepared to overlook this, then the minor details of this year's deliberations, the fixing of quotas for the few surviving more or less healthy stocks, can be regarded as mildly successful. But should one overlook the fact that an international commission, operating for nearly thirty years has reduced to unexploitable dimensions the stocks of blue and humpback, whales (the gray and right whales were virtually exterminated before they started), and in the past few years has also pushed the fin whale over the brink everywhere except in a single area of the Antarctic, and another in the North Atlantic? Sei whales in two areas and male sperm whales in another area are also 'protection stocks', that splendid euphemism for 'nearly exterminated stocks'. The remaining stocks of fin and sei whales, so recently the mainstay of the whaling industry, are now classed as sustained management stocks, under close control and with small quotas, as are also the minke whale (for which there has only been a quota for one year) in one area of the southern oceans and one of the northern, and sperm whales in certain areas. The only stocks still in a reasonably healthy condition are the 